\title{
Naval Diplomacy: Upaya Defensif Indonesia dalam Konflik Laut Tiongkok Selatan di Era Joko Widodo
}

\author{
R. Wing Witjahyo O. W. Poespojoedho \\ Universitas Diponegoro
}

\begin{abstract}
ABSTRAK
Konflik yang melibatkan banyak negara di Laut Tiongkok Selatan belum berakhir atau mereda. Telah terjadi peningkatan pada tekanan dan klaim antara negara-negara dan Indonesia berpartisipasi dalam konflik ini. Sebagai negara kepulauan terbesar di dunia sekaligus anggota ASEAN yang menjunjung perdamaian, keamanan, dan stabilitas regional, Indonesia dituntut untuk memainkan peranan aktif dalam konflik ini. Dalam konflik ini, Indonesia menggunakan naval diplomacy sebagai cara untuk mencapai resolusi konflik yang efektif. Kajian ini menggunakan konsep sea power dan naval diplomacy untuk menjelaskan langkah-langkah pemerintah Indonesia di bawah kepemimpinan Joko Widodo dalam merespon konflik yang mencakup teritorinya di Laut Tiongkok Selatan. Penelitian ini menunjukkan bahwa kebijakan Indonesia untuk menggunakan naval diplomacy di Laut Tiongkok Selatan memiliki hasil yang positif dan efektif dalam mencapai resolusi konflik dan kondisi damai, yang selama ini terhambat dengan berbagai tantangan yang ada
\end{abstract}

Kata-kata kunci: Laut Tiongkok Selatan, Resolusi Konflik, Naval Diplomacy, Sea Power, Pemerintahan Presiden Joko Widodo

The conflict involving many countries in the South China Sea has not ended nor subsided. Regional tension and claims between countries are increasing and Indonesia participates in this round of conflict. As the world's largest archipelagic country and an ASEAN member country that upholds peace, security and regional stability, Indonesia then has to play an active role in the conflict. In order to do so, Indonesia is using naval diplomacy as a way to achieve effective conflict resolution within the region. Regarding the phenomenon, this study used the concept of sea power and naval diplomacy to explain measures that have been taken by the Indonesian government under Joko Widodo's presidency in resolving the conflicts involving its territories in the South China Sea. The author's analysis showed that Indonesia's policies of using naval diplomacy in the South China Sea conflict have a positive and effective outcome in achieving conflict resolution and peace condition that has been confined by longterm obstacles and challenges.

Keywords: South China Sea, Conflict Resolution, Naval Diplomacy, Concept of Sea Power, Administration of President Joko Widodo 
Berkaitan dengan kedaulatan Indonesia dan kestabilan regional, telah terjadi konflik berkepanjangan yang cukup besar dan memiliki risiko cukup tinggi untuk pecahnya perang terbuka di wilayah Laut Tiongkok Selatan. Konflik Laut Tiongkok Selatan pada dasarnya diawali oleh perebutan wilayah yang memiliki nilai vital dan penting bagi kepentingan beberapa negara. Konflik ini terjadi di Laut Tiongkok Selatan, yang memiliki luas sekitar 3.500.00o kilometer persegi, dan mulai memanas sejak tahun 2011 (FKP Maritim 2012). Konflik ini melibatkan banyak aktor negara, khususnya negara-negara yang terletak di Asia Pasifik dan sebagian negara Association of Southeast Asian Nations (ASEAN), meskipun tidak menutup kemungkinan intervensi dan kepentingan-kepentingan negara-negara non-Asia yang terlibat dalam konflik ini. Beberapa negara berdaulat yang terlibat langsung di dalam konflik ini meliputi Brunei Darussalam, Republik Rakyat Tiongkok, Republik Tiongkok atau Taiwan, Malaysia, Filipina, dan Vietnam.

Indonesia, sebagai salah satu negara yang paling vokal dan memiliki bargaining power terkuat dalam ASEAN, telah mengupayakan berbagai macam diplomasi untuk mencapai resolusi konflik di Laut Tiongkok Selatan. Sebagai contoh, melalui upaya diplomasinya, pemerintah Indonesia turut berpartisipasi dalam penyusunan Declaration on the Conduct (DoC) of Parties in The South China Sea pada tahun 2002, melakukan kegiatan kooperatif yang tertera di dalam DoC dengan tetap menghormati kedaulatan dan integritas negara-negara lain, dan melakukan upaya yang konkret untuk memastikan terwujudnya Code of Conduct (CoC) untuk diterapkan di Laut Tiongkok Selatan.

Satu hal yang menarik disini adalah ketika pembentukan DoC semenjak tahun 2002, yang hingga tahun 2015 belum menemukan kata kesepakatan antara negara-negara yang memiliki klaim di Laut Tiongkok Selatan. Ketidaksepakatan ini khususnya tampak pada kepulauan Paracel dan Spratly. Indonesia sebagai pihakpenengah dan tidak sebagai negara pengklaim lebih mengutamakan pembangunan kekuatan maritim Indonesia dan telah mengupayakan bentuk diplomasi yang melibatkan unsur kekuatan militer, yaitu Tentara Nasional Indonesia Angkatan Laut (TNI-AL). Indonesia berusaha untuk menjaga kedaulatan nasional atas wilayah-wilayahnya sekaligus mewujudkan perdamaian dan stabilitas kawasan di Laut Tiongkok Selatan, mengingat betapa strategis dan pentingnya Laut Tiongkok Selatan bagi Indonesia dan negara-negara lain di kawasan ini. 


\section{Sea Power dan Naval Diplomacy}

Artikel ini menggunakan asumsi dasar dari teori neo-realis yang dikemukakan oleh Kenneth Waltz. Berangkat dari konsep dasar teori realis, yang memandang negara sebagai aktor utama dalam sistem internasional yang bersifat anarki dan konfliktual, maka muncullah defensive realism sebagai pengembangan teori neorealisme. Waltz (1979) menjelaskan bahwa perilaku sebuah negara dalam mengambil kebijakan terikat pada struktur anarkis dari sistem internasional. Waltz juga berpendapat bahwa negara secara intrinsik tidaklah agresif dan bahwa "perhatian pertama negara bukan untuk memaksimalkan kekuatan saja tetapi juga untuk mempertahankan posisi mereka dalam sistem" (Waltz 1979). Dalam dinamika yang terjadi dalam sistem internasional, terutama dalam situasi konflik, setiap negara akan melakukan apapun yang dapat dilakukan untuk bertahan dalam dunia internasional, termasuk meningkatkan keamanan negara menggunakan pengembangan kekuatan militer.

Sebagai sebuah organisasi yang membutuhkan upaya dalam mempertahankan diri, negara memerlukan kekuatan militer beserta instrumen-instrumen pendukungnya. Akan tetapi, karena resiko dan harga yang harus dibayar dari pecahnya perang sangatlah tinggi, maka diperlukan manajemen dan kontrol terhadap penggunaan kekuatan militer untuk meminimalisasi potensi perang. Di sinilah terletak peran serta fungsi utama negara sebagai sebuah organisasi (Waltz 1979). Selain itu, artikel ini juga memperhitungkan asumsi dasar dari teori defensif realis, yang dapat dilihat pada kutipan berikut:

"Only if states recognize 'the same rules of the game" and play 'for the same limited stakes' can the balance of power fulfill its functions for international stability and national independence" "(Morgenthau 1973).

Dari asumsi dasar teori defensif realis tersebut, artikel ini menganalisis kasus upaya Indonesia untuk mencapai resolusi konflik menggunakan konsep Sea Power dan Naval Diplomacy. Indonesia memiliki latar belakang sebagai negara maritim dan kepulauan yang 70 persen wilayahnya merupakan lautan. Sebagai konsekuensi dari latar belakang ini, Indonesia dituntut untuk menyesuaikan segala konsep pertahanan, kebijakan, ekonomi, hingga diplomasi yang digunakannya berdasarkan kondisi geografis yang dimilikinya. 
Konsep Sea Power merupakan konsep yang dikembangkan oleh Alfred Thayer Mahan, seorang perwira Angkatan Laut AS di abad ke-19 di dalam bukunya yang berjudul The Influence of Sea Power Upon History. Buku ini berfokus pada pentingnya kekuatan laut bagi sebuah negara. Sea power merupakan unsur terpenting bagi kemajuan dan kejayaan suatu negara dengan wilayah laut yang luas. Apabila kekuatan-kekuatan laut tersebut diberdayakan, maka akan kesejahteraan dan keamanan negara tersebut akan mengalami peningkatan. Sebaliknya, jika kekuatan-kekuatan laut tersebut diabaikan, maka akan mengakibatkan kerugian atau bahkan meruntuhkan negara tersebut. Bagi sebuah negara, laut merupakan salah satu hal yang sangat penting dan menjadi fokus utama bagi suatu negara terutama bagi negara dengan wilayah laut yang luas. Menurut Mahan, posisi geografis suatu negara akan berpengaruh pada kebijakan penting untuk meningkatkan konsentrasi atau pelebaran fokus pada laut terutama berkaitan dengan kekuatan angkatan laut negara tersebut (Mahan 1890). Menurut kutipan Mahan di atas, disebutkan bahwa laut adalah faktor yang masih sangat penting bagi sebuah keamanan negara terutama pengembangan kekuatan angkatan laut. Lebih lanjut, Mahan juga melihat bahwa dalam pengembangan kekuatan angkatan laut melalui sea power, faktor yang berpengaruh bukan saja tentang total luas mil persegi yang dimiliki suatu negara, namun juga panjang garis pantai suatu negara dan karakter pelabuhannya yang dimilikinya (Mahan 1890). Setelah unsur sea power terpenuhi oleh suatu negara, maka secara otomatis kekuatan angkatan laut negara tersebut pun akan berkembang menjadi lebih kuat. Dengan angkatan laut yang kuat, maka negara tersebut memiliki kemampuan dan potensi untuk menggunakan kekuatan angkatan laut dalam banyak hal.

Dalam artikel ini, Indonesia yang bertujuan untuk mencapai resolusi konflik Laut Tiongkok Selatan menggunakan unsur sea power dan kekuatan angkatan laut sebagai salah satu bentuk upaya diplomasi, yaitu naval diplomacy atau diplomasi angkatan laut. Negara dapat merespon konflik teritorial atau wilayah yang melibatkannya melalui beberapa tindakan seperti diplomasi damai, menunjukkan kekuatan militer yang dimiliki, ataupun kombinasi keduanya. Ken Booth (2014) menjelaskan bahwa kekuatan maritim suatu negara memiliki 3 fungsi utama yang dikenal sebagai Booth Trinity, yaitu Military, Constabulary atau Policing, dan Diplomacy. Konsep yang dikemukakan oleh Booth ini kemudian dikembangkan secara lebih terperinci oleh Geoffrey Till dengan penekanan dan fokus terhadap 
fungsi diplomasi dari kekuatan maritim suatu negara. Penekanan dan fokus ini dapat dilihat pada Framework Naval Diplomacy oleh Till berikut.

\section{Grafik 1. Framework Naval Diplomacy oleh Geoffrey Till}

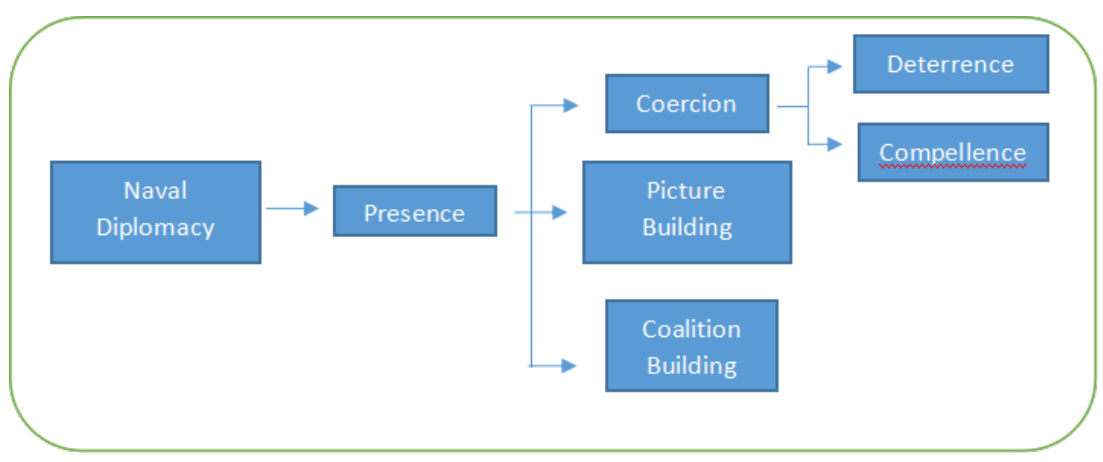

Sumber: Agastia (2016).

Konsep naval diplomacy di atas memiliki 2 tahap, yaitu presence, coercion/picture building/coalition building, dan unsur lanjutan dari coercion yaitu deterrence/compellence. Tahapan-tahapan inilah yang akan menjadi konsep utama dalam artikel ini untuk menjelaskan upaya naval diplomacy Indonesia di era kepemimpinan Presiden Joko Widodo untuk mencapai resolusi konflik di Laut Tiongkok Selatan secara terperinci.

\section{Keterlibatan Indonesia Dalam Konflik dan Postur Kekuatan TNI AL di era Joko Widodo}

Pada tahun 2009, Republik Rakyat Tiongkok menyerahkan note verbale kepada Sekretaris Jenderal PBB, yakni suatu pernyataan diplomatik yang dikenal sebagai Sembilan Garis Putus atau nine dashed lines untuk membatasi dan memperjelas klaim mereka di Laut Tiongkok Selatan. Dalam dokumen tersebut, klaim teritorial Beijing melanggar Zona Ekonomi Eksklusif Indonesia dari batas wilayah Kepulauan Natuna (United Nations 2009). Garis-garis tersebut dimulai dengan klaim utama Tiongkok di Kepulauan Paracel dan Spratley serta terus memanjang ke selatan dan turut menyertakan beberapa wilayah lain seperti Teluk Tonkin di Vietnam, Kepulauan Natuna di Indonesia, dan Scarborough Shoal di Filipina. Selain dengan Tiongkok, Indonesia juga bersengketa terkait wilayah seputar Kepulauan Natuna dan Laut Tiongkok Selatan dengan Malaysia dan Vietnam. Indonesia dan Malaysia seringkali 
terlibat konflik dan ketegangan di sekitar Selat Malaka. Selat Malaka merupakan choke point yang menghubungkan Samudera Hindia dengan Laut Tiongkok Selatan. Selat ini merupakan salah satu jalur pelayaran penting di dunia, dan satu dari sembilan selat dan terusan strategis di dunia. Hal tersebut menjadikan Selat Malaka lintasan terdekat dari Laut Hindia menuju Laut Tiongkok Selatan serta Pasifik dan sebaliknya, sehingga telah menjadi urat nadi perekonomian dunia (Kompasiana 2017). Sedangkan, dalam insiden Indonesia dengan Vietnam ketika TNI-AL menangkap kapal penangkap ikan illegal milik Vietnam di Natuna, Pemerintah Vietnam menyebutkan bahwa insiden tersebut terjadi ketika dua kapal ikan dari negaranya berada pada 132 nautical miles atau 245 kilometer di sisi tenggara Pulau Con Dao. Pulau tersebut masuk ke dalam wilayah administrasi Provinsi Ba Ria-Vung, sehingga tempat terjadinya insiden tersebut diklaim masih merupakan wilayah perairan ZEE Vietnam (CNN Indonesia 2017).

Selain klaim 9 dashed line Tiongkok, sengketa yang terjadi antara Indonesia dengan negara lain juga menjadikan Laut Tiongkok Selatan area panas yang rawan akan penggunaan kekuatan militer secara ofensif hingga potensi pecahnya perang terbuka. Sebagai negara yang menjunjung tinggi kedaulatan dan keamanan nasional di wilayahnya, Indonesia juga terhitung mulai meningkatkan kekuatan militernya secara masif, khususnya di matra laut melalui TNI-AL pada era Pemerintahan Joko Widodo. Akan tetapi, melalui kebijakan luar negerinya dan perannya sebagai pemimpin de facto ASEAN, Indonesia juga berkepentingan untuk berkontribusi langsung dalam usaha resolusi konflik di Laut Tiongkok Selatan untuk mencapai kestabilan, keamanan dan perdamaian regional di Asia Tenggara dan Asia Pasifik. Salah satu upaya untuk mencapai hal tersebut adalah dengan menggunakan kekuatan militer yang telah dikembangkan sebagai salah satu bentuk diplomasi Indonesia dalam konflik ini. Menurut Panglima TNI Marsekal Hadi Tjahjanto, saat ini TNI tengah meningkatkan diplomasi militer dalam rangka mendukung diplomasi luar negeri guna memperkuat posisi Indonesia pada percaturan dunia internasional. Dalam kerjasama tersebut, terdapat beberapa poin yang harus ditekankan, seperti pengembangan kemampuan, pembangunan interoperabilitas, dan pembangunan kepercayaan antara negara-negara yang ada (Antaranews 2018).

Untuk memenuhi peningkatan kekuatan yang ditargetkan, pemerintah melalui program Minimum Essential Force atau MEF 
akan meningkatkan kekuatan militer Indonesia secara bertahap hingga tahun 2024. Program ini memerlukan anggaran besar, yang akan difokuskan pada pembelian dan modernisasi alutsista, pembangunan pangkalan militer, dan peningkatan kualitas sumber daya manusia. Presiden Joko Widodo menekankan bahwa fokus pengadaan alutsista tidak saja untuk memenuhi postur MEF 2024, namun juga untuk menyesuaikan kondisi geografis negara Indonesia yang berbentuk kepulauan (Sindonews Nasional 2017). Presiden Joko Widodo pada rapat terbatas mengenai modernisasi senjata dan sistem pertahanan Indonesia menargetkan bahwa pada tahun 2024 Indonesia mampu memenuhi postur kekuatan pokok pertahanan minimum bagi TNI Angkatan Darat, TNI Angkatan Udara, dan TNI Angkatan Laut. Modernisasi ini memerlukan total nilai anggaran belanja senjata yang mencapai sekitar US\$ 7,74 miliar, yang merupakan rencana belanja persenjataan hingga tahun 2019. Setiap angkatan mendapatkan alokasi anggaran belanja masing-masing hingga tahun 2019. Anggaran untuk TNI-AD adalah senilai US\$ 1,51 miliar, sedangkan anggaran belanja senjata bagi TNI-AL adalah sekitar US\$ 3,27 miliar dan TNI-AU akan menerima anggaran sebesar US\$ 2,85 miliar. (Jakarta Greater 2016). Dapat dilihat bahwa dari total anggaran belanja alutsista militer, TNI-AL mendapatkan porsi paling besar sesuai dengan tujuan nasional yang telah direncanakan oleh pemerintah, yakni memenuhi MEF yang sesuai dengan yang diperintahkan oleh Presiden Joko Widodo dan disetujui oleh DPR.

Langkah ini membawa efek yang cukup besar bagi posisi dan daya tawar Indonesia di kancah internasional. Melalui peningkatan keseluruhan dari 3 matra, data periodik dari Global Fire Power menunjukkan bahwa kekuatan militer Indonesia telah menempati posisi ke-15 dunia di masa kepemimpinan Presiden Joko Widodo. Terkhusus untuk TNI-AL, Indonesia menempati peringkat ke-10 dunia, peringkat pertama di Asia Tenggara, dan peringkat ke-3 di Asia Pasifik setelah Korea Utara dan Tiongkok. Dengan potensi kekuatan militer yang besar ini, Indonesia mencoba untuk menggunakannya sebagai salah satu alat diplomasi untuk mencapai resolusi konflik di Laut Tiongkok Selatan. 


\section{Analisis Upaya Naval Diplomacy Indonesia Dalam Konflik Laut Tiongkok Selatan}

Seperti yang telah ditulis di awal pembahasan, langkah yang dilakukan oleh Indonesia dilandasi oleh sikap defensif yang sangat kuat. Indonesia tidak ingin menggunakan kekuatan militernya secara offensif, terlebih lagi di kawasan yang sangat tidak stabil seperti Laut Tiongkok Selatan. Hal ini dikarenakan perilaku offensif di kawasan tersebut hanya akan memperrumit masalah dan meningkatkan kemungkinan pecahnya perang terbuka skala besar. Namun demikian, sebagai negara kepulauan yang sangat luas, Indonesia memiliki potensi untuk meningkatkan salah satu unsur unggulan untuk kekuatan angkatan lautnya berdasarkan kondisi geografis yang dimiliki. Unsur inilah yang disebut sebagai unsur sea power. Menurut Mahan (1890), terdapat 3 faktor yang memengaruhi kuatnya angkatan laut suatu negara. Tidak hanya membutuhkan alutsista yang kuat dan disegani, negara juga harus memperhitungkan faktor geografis seperti luas wilayah laut, panjang garis pantai dan karakter pelabuhan negara tersebut. Selain itu, Robert Kaplan (2009) juga menuturkan bahwa geografi secara luas akan menjadi determinan yang memengaruhi berbagai peristiwa lebih dari pada yang pernah terjadi sebelumnya.

Wilayah Indonesia yang strategis, baik secara geopolitik maupun ekonomi, memungkinkan negara ini untuk menjadi jembatan utama bagi pelayaran, ekonomi, maupun politik antarbenua. Hal ini didukung dengan penjelasan dari Kolonel Laut Aji Nurmanihadi bahwa perairan Indonesia merupakan perairan yang sangat strategis, karena berperan sebagai Sea Line of Communication atau SLOC bagi kapal-kapal yang berlayar. Hal ini disebabkan oleh posisi Indonesia yang terletak di antara Benua Asia dan Benua Australia, serta antara Samudera Hindia dan Samudera Pasifik (Pusat Hidrografi dan Oseanografi TNI Angkatan Laut 2017). Faktor lain yang menguntungkan Indonesia dalam meningkatkan sea power adalah panjang garis pantai. Dengan garis pantai sepanjang 108.000 kilometer, Indonesia menjadi negara dengan garis pantai terpanjang kedua di dunia. Indonesia lantas memiliki potensi besar di bidang industri bioteknologi kelautan, perairan dalam atau deep ocean water, wisata bahari, energi kelautan, mineral laut, pelayaran, pertahanan, serta industri maritim. Apabila pembangunan di sektor kelautan dan perikanan dilakukan secara optimal, kesejahteraan masyarakat akan meningkat dan kehidupan generasi mendatang akan terjamin (Kementerian Peri- 
kanan dan Kelautan Republik Indonesia 2017). Dalam bidang pertahanan, hal ini juga sangat menguntungkan bagi Indonesia. Berdasarkan Undang-undang Nomor 3 Tahun 2002 tentang Pertahanan Negara, pertahanan negara disusun dengan memperhatikan kondisi geografis Indonesia sebagai negara kepulauan serta dengan mengedepankan konsep pertahanan berlapis.

Konsep pertahanan berlapis ini mengedepankan kekuatan TNI, khususnya TNI-AL. Tindakan militer untuk menghadang serangan atau agresi negara lain dalam rangka preemptive dilaksanakan dengan mengerahkan kekuatan TNI sejauh mungkin sebelum musuh memasuki wilayah Zona Ekonomi Eksklusif atau ZEE Indonesia. Pertahanan militer untuk menghadapi agresi musuh yang telah masuk wilayah Indonesia dilaksanakan dalam susunan pertahanan mendalam dengan mengerahkan kekuatan TNI untuk mencegat dan menghancurkan kekuatan militer lawan dari luar batas ZEE hingga masuk ke pantai dan daratan wilayah Indonesia (Strategi Perta-hanan Republik Indonesia 2014). Dengan demikian, dapat diartikan bahwa TNI-AL adalah matra lapis pertama dan berada pada posisi terluar di dalam konsep pertahanan Indonesia. Transisi kekuatan matra TNI terjadi di pantai, agar semua elemen Republik Indonesia dapat saling memberikan dukungan dalam menghadapi kemungkinan terburuk berupa serangan musuh.

Unsur sea power terakhir yang dicetuskan oleh Mahan adalah karakter pelabuhan, seperti kuantitas dan kualitas pelabuhan. Unsurunsur ini akan melengkapi sebagai kesatuan sea power yang membentuk kekuatan angkatan laut yang kuat. Indonesia merupakan negara kepulauan yang sangat luas. Hal ini menuntut Indonesia untuk membangun infrastruktur maritim yang memadai untuk meningkatkan perkembangan ekonomi, distribusi logistik yang merata, kemudahan transportasi, dan mobilisasi pertahanan negara. Pembangunan pelabuhan Indonesia pada era pemerintahan Joko Widodo mengalami kemajuan yang sangat pesat. Hingga tahun 2019, pemerintah telah membangun 32 pelabuhan yang tersebar merata di seluruh Indonesia (Detik Finance 2019). Selain pelabuhan umum, Indonesia telah memiliki sebanyak 14 Pangkalan Utama TNI-AL, yang terdiri dari 63 pangkalan dan pos TNI-AL serta menjadi bagian integral dari 3 satuan Armada TNI-AL yang bertugas. Selama masa Pemerintahan Joko Widodo, telah dilakukan pembangunan 3 Pangkalan Militer TNI-AL yang baru, yaitu Pangkalan Utama Kelas A dan Pangkalan Kapal Selam yang terletak di Kepulauan Natuna, dan Pangkalan Kelas C di Kulonprogo, Daerah Istimewa Yogyakarta. 
Pangkalan Utama TNI-AL di Natuna, utamanya, dibentuk sebagai respons terhadap beberapa kejadian dan sengketa yang melibatkan Indonesia di Laut Tiongkok Selatan (Tribunnews 2018a).

Pangkalan militer berfungsi sebagai tempat pertahanan utama dan titik fokus mobilisasi di wilayah tersebut. Selain itu, pangkalan militer juga mempermudah pihak militer untuk melakukan pemantauan wilayah di sekitarnya. Kemudian, pelabuhan-pelabuhan umum yang dibangun akan mempermudah alur suplai logistik terhadap kebutuhan militer seperti distribusi bahan bakar, makanan dan ransum, serta kebutuhan-kebutuhan lainnya. Dengan operasi logistik yang efisien, militer dapat meringankan beban persediaan dan peralatan untuk memangkas waste, seperti transportasi logistik, pergerakan-yakni pengangkutan dan pemindahan barang-dan pada saat bersamaan peningkatan ketahanan atau sustainability pasukan di medan perang (Radio Republik Indonesia 2019).

Dengan unsur sea power dan alutsista yang terpenuhi dengan baik, maka Indonesia melalui TNI-AL telah memiliki daya tawar yang cukup untuk melakukan naval diplomacy dalam konflik Laut Tiongkok Selatan. Istilah naval diplomacy mengacu pada penggunaan instrumen kekuatan angkatan laut suatu negara, seperti kapal perang dan alutsista lain, untuk mendukung kebijakan luar negeri negara tersebut dan untuk melakukan penyerangan atau penembakan senjata. Oleh karena itu, upaya ini melibatkan penggunaan kekuatan angkatan laut dalam berbagai bentuk kegiatan, seperti: (1) komunikasi secara intens; dan (2) penerjunan kekuatan langsung sebagai upaya negosiasi dalam sebuah krisis, konflik, atau secara lebih umum untuk meningkatkan daya tawar suatu negara. Selain itu, naval diplomacy melalui angkatan laut juga dapat digunakan untuk meningkatan pengaruh suatu negara dalam pemilihan opsi penawaran kerja sama. Diplomasi jenis ini bahkan dapat digunakan dengan memperlihatkan kekuatan tersebut sebagai unsur pendukung, atau kekuatan yang mewakili tugas tertentu yang diberikan negara terhadap angkatan laut tersebut (Booth 2014).

\section{Presence}

Tahap pertama dari naval diplomacy yang dilakukan oleh Indonesia adalah memastikan telah terpenuhinya unsur presence atau kehadiran. Kehadiran di sini memiliki perbedaan makna dengan kehadiran yang merujuk pada kata existence atau eksistensi. Apabila kekuatan dari angkatan laut dibutuhkan sewaktu-waktu oleh negara, maka negara membutuhkan kehadiran yang 'cepat dan nyata' dan dapat 
diterjunkan di area yang telah diperintahkan. Secara sederhana, kehadiran atau presence dari angkatan laut adalah dengan ketersediaan beragam alutsistanya, seperti kapal perang. Di sisi lain, istilah existence atau eksistensi merujuk pada bentuk yang lebih sederhana, yaitu adanya bentuk kelembagaan dari angkatan laut suatu negara (Till 2009).

Dalam Framework Naval Diplomacy, langkah diplomasi yang akan dilakukan setelah unsur presence terpenuhi adalah tahap coercion atau langkah koersi, picture building atau pembangunan kesan dan gambaran, dan coalition building atau pembangunan koalisi dan kerjasama. Menurut Geoffrey Till (2009), ketiga fungsi ini memiliki perbedaan tujuan dan cara. Namun, ketiganya mempunyai sifat berlanjut dan saling melengkapi, seperti sebuah spektrum di mana batas antara fungsi-fungsi tersebut samar. Oleh karena itu, kegiatan yang mereka lakukan mungkin berbeda bukan pada jenis dan fungsinya, namun hanya pada tingkatannya, sehingga kekuatan maritim atau dalam hal ini angkatan laut suatu negara dapat terlibat dalam lebih dari satu jenis kegiatan secara bersamaan. Dapat dianalogikan bahwa angkatan laut suatu negara yang mencegat kapal ilegal dari negara lain yang penuh dengan senjata mungkin dapat melakukan proses menghalangi, memaksa, mengusir dan membangun koalisi atau kerjasama pada saat bersamaan, terlepas dari kondisi yang ada (Till 2009).

\section{Picture Building}

TNI-AL telah memiliki image dan kesan yang kuat serta terus berkembang baik. Kualitas personel, persenjataan dan alutsista, serta kesejahteraan dan kuantitas personel TNI-AL telah menunjukkan bahwa Indonesia memiliki kapabilitas yang hebat di bidang militer. Maka, usaha picture-building untuk membangun postur TNI-AL yang kuat telah berhasil. Akan tetapi, selain memberikan kesan yang kuat dan siap, TNI-AL juga harus mampu menunjukkan kesan yang lembut dan mampu menjadi penengah di dalam konflik yang sedang terjadi. Dalam tugasnya menurut Undang-Undang No. 34 tahun 2004, TNI memiliki tugas pokok yang dibagi menjadi 2 jenis, yakni Operasi Militer untuk Perang atau OMP dan Operasi Militer Selain Perang atau OMSP. Dalam OMSP, tugas-tugas TNIAL tidak terkhusus pada perang, penyerangan, dan penggunaan senjata, namun memiliki jangkauan yang jauh lebih luas dalam banyak aspek seperti sosial, politik dan kemanusiaan. Melalui beragam misi kemanusiaan, serta dengan didukung oleh alutsista yang handal, maka usaha picture-building dapat memberikan kesan 
bahwa TNI-AL mampu menggunakan kekuatan mereka dalam hal yang humanis dan mendukung perdamaian.

\section{Coalition Building}

Coalition Building, pada sisi lain, adalah serangkaian kegiatan yang secara tegas dimaksudkan untuk mengamankan tujuan kebijakan luar negeri suatu negara bukan dengan cara mengancam musuh potensial, tetapi dengan memengaruhi perilaku sekutu dan pihakpihak yang berpotensi menjadi teman. Coalition building meliputi berbagai macam jenis kerjasama, seperti latihan bersama, transfer of knowledge, hingga perdagangan dan pengembangan alutsista bersama atau joint research (Till 2009). Koalisi di sini bukan dimaksudkan berbentuk ikatan yang formal dan mengikat seperti pakta, persekutuan, atau organisasi formal, melainkan hal-hal yang bersifat lebih sederhana dan dinamis. Dibutuhkan proses yang panjang dan berkelanjutan atau 'Building' agar efek dari coalition building yang dilakukan oleh Indonesia menghasilkan hasil yang signifikan. Salah satu contohnya adalah melalui naval diplomacy berbentuk latihan bersama, seperti yang telah disebutkan di atas. Indonesia secara berkala dan konsisten terus melakukan banyak latihan bersama angkatan laut berskala internasional yang melibatkan banyak negara, termasuk aktor-aktor yang terlibat di dalam konflik Laut Tiongkok Selatan. Coalition building dapat dilakukan dalam Operasi Militer untuk Perang maupun Operasi Militer non-Perang.

Salah satu latihan militer angkatan laut terbesar yang diselenggarakan oleh Indonesia adalah latihan bersama yang melibatkan angkatan laut seluruh negara ASEAN dan negara-negara lainnya. Latma Komodo tahun 2014 yang dilaksanakan di Batam dan Anambas bahkan telah menjadi latihan angkatan laut terbesar di Asia Pasifik. Menurut Kepala Staf Angkatan Laut, Laksamana TNI Marsetio, Latma Multilateral Komodo 2014 memiliki dimensi kepentingan nasional, regional dan internasional, yakni meningkatkan hubungan antara negara-negara ASEAN dan menjaga stabilitas keamanan kawasan (TNI 2014). Latihan ini dilakukan setiap 2 tahun sekali di Indonesia dan menuai respons yang sangat positif dari banyak negara.

Naval Diplomacy berupa coalition building yang dilakukan juga meliputi upaya pengembangan, produksi, dan perdagangan alutsista dengan negara-negara lain, terutama di ASEAN-termasuk negaranegara yang memiliki tumpang tindih klaim dengan Indonesia. Dalam beberapa tahun terakhir, Indonesia telah melakukan kerja 
sama pengembangan dan penjualan alutsista yang didominasi oleh alutsista angkatan laut dengan beberapa negara seperti Malaysia, Thailand, Filipina, Brunei, dan juga Tiongkok.

\section{Coercion}

Langkah naval diplomacy selanjutnya adalah coercion atau koersi, yang merupakan upaya penggunaan ancaman kekuatan untuk memengaruhi sikap dari pihak lain dan mendapatkan apa yang diinginkan tanpa harus menggunakan kekuatan tersebut secara nyata untuk kekerasan seperti perang berskala penuh (Till 2009). Dari dua bentuk coercion yang disebutkan oleh Till (2009), Indonesia menggunakan langkah deterrence sebagai salah satu upaya naval

diplomacy. Menurut Buku Putih Kementerian Pertahanan Republik Indonesia (2014), TNI sebagai benteng pertahanan nasional memiliki strategi pertahanan berlapis dengan prioritas pertahanan berdasarkan deterrence atau penangkalan. Pada masa damai, pertahanan negara diselenggarakan untuk mewujudkan daya tangkal bangsa dan negara yang tangguh. Penangkalan yang handal dapat mencegah terjadinya perang sehingga perlu terus dibangun dan dikembangkan. Penangkalan merupakan pilihan dalam upaya pertahanan, sehingga daya tangkal harus dibangun dan dikembangkan sejak dini serta dilaksanakan secara berkesinambungan (Buku Putih Kementerian Pertahanan Republik Indonesia 2014). Salah satu upaya deterrence Indonesia dalam menghadapi konflik di Laut Tiongkok Selatan adalah melalui pembangunan pangkalan TNI-AL di Natuna, yang merupakan hotspot atau titik panas konflik yang melibatkan Indonesia. Setelah diresmikan pada tahun 2018, pangkalan TNI-AL yang bertempat di Selat Lampa, Natuna tersebut nantinya akan berperan sebagai satuan terdepan dalam menghadapi ancaman potensial dan diharapkan mampu merespon dengan cepat potensi ancaman yang datang. (Tribunnews 2018b).

\section{Kesimpulan}

Upaya naval diplomacy yang telah dilakukan oleh Indonesia mampu memberikan reaksi positif dari negara-negara yang terlibat dalam konflik Laut Tiongkok Selatan dan hasil yang signifikan dalam upaya resolusi konflik ini dan menurunkan ketegangan antarnegara. Indonesia mengajak negara-negara ASEAN melakukan patroli bersama di Laut Tiongkok Selatan pada tahun 2018, sebagai bentuk dari coalition building yang merupakan salah satu un- 
sur naval diplomacy Indonesia. Ajakan tersebut mendapat tanggapan positif dari Tiongkok, yang mengapresiasi tindakan Indonesia dan mengharapkan bahwa patrol bersama yang diinisiasi Indonesia akan mampu memperbaiki dan menjadikan situasi di Laut Tiongkok Selatan semakin stabil (Republika 2018). Sebelumnya, pada tahun 2016, Indonesia, Malaysia dan Filipina telah menandatangani kerangka kerja untuk pengaturan kerja sama Trilateral 3 Joint Working Group (JWG) mengenai permasalahan di area keamanan maritim yang menjadi perhatian bersama. Permasalahanpermasalahan ini meliputi isu-isu seperti perbatasan, perompakan, dan Laut Tiongkok Selatan. Kerja sama ini meliputi patroli bersama angkatan laut ketiga negara di area yang rawan. (Setnas ASEAN 2016). Respons positif juga datang dari Vietnam, yang memandang Indonesia sebagai mitra penting dalam bidang pertahanan, khususnya yang melibatkan angkatan laut dan coast guard kedua negara. Bidang tersebut juga menjadi komponen penting yang memperkuat hubungan bilateral kedua negara (Medcom 2017).

Pada tahun 2019, sebagai respons positif atas inisiatif Indonesia untuk mengajak angkatan laut negara-negara ASEAN berpatroli di Laut Tiongkok Selatan, Pemerintah Republik Rakyat Tiongkok akan menggelar latihan bersama dengan angkatan laut negara-negara Asia Tenggara-terkecuali Timor Leste dan Kamboja, yang tidak memiliki kepentingan di Laut Tiongkok Selatan-di perairan lepas pantai timur wilayah negaranya (Viva 2019). Tidak hanya respons positif dan pujian dari negara-negara lain, Indonesia juga berhasil mendorong terbentuknya resolusi konflik di Laut Tiongkok Selatan secara mengikat melalui DoC dan CoC, yang didukung dengan upayaupaya diplomasi Indonesia seperti naval diplomacy. Pada tahun 2017, Pemerintah Tiongkok dan ASEAN berhasil menyepakati dan menandatangani kerangka kesepakatan atau CoC terkait Laut Tiongkok Selatan dalam Pertemuan ke-14 ASEAN-China Senior Officials Meeting on the Implementation of the Declaration on the Conduct of Parties in the South China Sea. Kesepakatan ini merupakan capaian penting dari ASEAN dan Tiongkok, mengingat DoC telah disetujui pada tahun 2002 dan konsultasi CoC telah dimulai sejak 2013 (Okezone 2017).

Pada tahun 2018, Tiongkok dan ASEAN menyepakati naskah tunggal untuk menegosiasikan $\mathrm{CoC}$ di Laut Tiongkok Selatan. Perkembangan dari upaya resolusi konflik yang diprakarsai oleh Indonesia ini terus menunjukkan hal yang positif dari waktu ke waktu, seiring dengan gencarnya Indonesia melakukan kerja sama 
keamanan intra-ASEAN. Hal tersebut disampaikan oleh Menteri Luar Negeri Tiongkok, Wang Yi, dalam Pertemuan Menteri Luar Negeri ASEAN di Singapura. Naskah tunggal tersebut diharapkan akan menjadi dasar dari negosiasi lebih lanjut mengenai $\mathrm{CoC}$ antara ASEAN dan Tiongkok di masa mendatang (Okezone 2018). Peran penting Indonesia juga diapresiasi oleh Mantan Menteri Luar Negeri Singapura, George Yeo, yang menyebutkan dalam sebuah konferensi keamanan yang diselenggarakan oleh Institute of Policy Studies atau IPS bahwa "Tanpa Indonesia, sangat sulit bagi ASEAN untuk menyatukan posisi bersama." (Matamata Politik 2019). Dengan sea power yang memadai, TNI-AL mampu membuat perubahan signifikan dalam upaya resolusi Laut Tiongkok Selatan yang selama ini terus mengalami hambatan. Peningkatan alutsista yang sangat pesat serta usaha naval diplomacy yang beragam merupakanbeberapa contoh yang membuktikan bahwa upaya diplomasi yang dilakukan oleh Pemerintah Indonesia melalui TNIAL tidak main-main, mengingat konflik Laut Tiongkok Selatan dapat berubah menjadi medan perang besar sewaktu-waktu apabila tidak ada kekuatan penengah di antara negara-negara yang berkonflik. 


\section{Daftar Pustaka}

\section{Buku dan Artikel dalam Buku}

Agastia, I Gusti Bagus Dharma, 2016. Maritime Security in the Indo-Pacific, $1^{\text {st }}$ ed. Yogyakarta: Graha Ilmu.

Booth, K., 2014. Law, force and diplomacy at sea, $1^{\text {st }}$ ed. New York: Routledge.

Kaplan, R., 2009. Foreign Policy no. 172. Washington: State Group, LLC.

Mahan, A. T., 1890. The Influence of Sea Power Upon History, $1^{\text {st }}$ ed. Boston: Little, Brown and Company.

Morgenthau, H. J., 1973. Politics Among Nations: The Struggle For Power and Peace. $5^{\text {th }}$ ed. New York: Knopf.

Till, G., 2009. Cass Series: Naval Policy and History, $2^{\text {nd }}$ ed. New York: Routledge.

Waltz, K. N., 1979. Theory of International Politics, $1^{\text {st }}$ ed. New York: Megraw Hill.

\section{Publikasi Resmi}

Buku Putih Kementerian Pertahanan Republik Indonesia 20142019, 2014. Jakarta: Kementerian Pertahanan Republik Indonesia.

Strategi Pertahanan Republik Indonesia, 2014. Jakarta: Kementerian Pertahanan Republik Indonesia.

\section{Artikel Online}

Antaranews, 2018. "TNI tingkatkan diplomasi militer dukung diplomasi luar negeri" [online]. dalam https://www.antaranews. com/berita/765135/tni-tingkatkan-diplomasi-militer-dukung-diplomasi-luar-negeri [diakses 19 April 2019].

CNN Indonesia, 2017. "Vietnam sebut Indonesia tembak nelayannya di Laut China Selatan" [online] dalam https://www. cnnindonesia.com/internasional/20170724150422- 
106-229947/vietnam-sebut-indonesia-tembak-nelayannya-di-lcs [diakses 14 April 2019].

Detik Finance, 2019. "Pemerintah Bangun 32 Pelabuhan Hingga 2019" [online]. dalam https://finance.detik.com/ infrastruktur/d-396846o/pemerintah-bangun-32pelabuhan-hingga-2019 [diakses 16 Mei 2019].

FKP Maritim, 2012. "Konflik Laut China Selatan Indonesia Untung atau Buntung" [online]. dalam http://www.fkpmar.org/ konflik-laut-china-selatan-indonesia-untung-ataubuntung/ [diakses 19 September 2019].

Jakarta Greater, 2016. "Indonesia Segera Borong Alutsista dan Senjata Baru” [online]. dalam https://jakartagreater.com/ indonesia-segera-borong-alutsista-dan-senjata-baru/ [diakses 18 Mei 2019].

Kementerian Perikanan dan Kelautan Republik Indonesia, 2017. "Direktorat Pengelolaan Ruang Laut - Refleksi 2017 dan Outlook 2018 Membangun dan Menjaga Ekosistem Laut" [online]. dalam https://kkp.go.id/djprl/artikel/2798refleksi-2017-dan-outlook-2018-membangun-danmenjaga-ekosistem-laut-indonesia-bersama-ditjenpengelolaan-ruang-laut [diakses 16 May 2019].

Matamata Politik, 2019. "Mata-mata politik: Dampak Pangkalan Militer Baru Indonesia di Laut China Selatan“ [online]. dalam https://www.matamatapolitik.com/analisisdampak-pangkalan-militer-baru-indonesia-di-laut-chinaselatan/ [diakses 10 Juni 2019].

Medcom, 2017. "Vietnam Sebut Indonesia Mitra Penting di Bidang Pertahanan" [online]. dalam https://www.medcom.id/ internasional/asia/8Kyv883N-vietnam-sebut-indonesiamitra-penting-di-bidang-pertahanan [diakses 29 Mei 2019].

Okezone, 2017. "Tiongkok dan ASEAN Capai Kesepakatan Soal Laut China Selatan" [online]. dalam https://news.okezone. $\mathrm{com} / \mathrm{read} / 2017 / 05 / 19 / 18 / 1695201 /$ tiongkok-dan-aseancapai-kesepakatan-soal-laut-china-selatan [diakses 20 Juni 2019]. 
Okezone, 2018. "ASEAN dan Tiongkok Sepakati Naskah Negosiasi CoC di Laut China Selatan" [online]. dalam https:// news.okezone.com/read/2018/o8/o3/18/1931400/ asean-dan-tiongkok-sepakati-naskah-negosiasi-coc-dilaut-china-selatan [diakses 22 Juni 2019].

Pusat Hidrografi dan Oseanografi TNI Angkatan Laut, 2017. "Pentingnya Peta Laut dalam Mewujudkan Indonesia sebagai Poros Maritim Dunia" [online]. dalam http:// pushidrosal.id/berita/4127/pentingnya-peta-laut-dalammewujudkan-indonesia-sebagai-poros-maritim-dunia/\# [diakses 15 Mei 2019].

Radio Republik Indonesia, 2019. "Fungsi Logistik Berperan bagi TNI Dalam Tugas Operasi Militer" [online]. dalam http://rri.co.id/post/berita/638489/nasional/fungsi_ logistik_berperan_bagi_tni_dalam_tugas_operasi_ militer.html [diakses 18 Mei 2019].

Republika, 2018. "Cina Tanggapi Soal Ajakan Indonesia Patroli Bersama di LCS" [online]. dalam https://internasional. republika.co.id/berita/internasional/asia/18/o3/17/ p5ppvr383-cina-tanggapi-soal-ajakan-indonesia-patrolibersama-di-lcs [diakses 22 Juni 2019].

Setnas ASEAN, 2016. "Kerja Sama Trilateral untuk Meningkatkan Keamanan Maritim"[online].dalamhttp://setnas-asean.id/ siaran-pers/read/kerja-sama-trilateral-untukmeningkatkan-keamanan-maritim [diakses 19 Juni 2019].

Sindonews Nasional, 2017. "Jokowi Ingin Pengadaan Alutsista Disesuaikan Kondisi Geografis" [online]. dalam https://nasional.sindonews.com/read/1224222/14/ jokowi-ingin-pengadaan-alutsista-disesuaikan-kondisigeografis-1501063699 [diakses 20 April 2019].

TNI, 2014. "Menkopolhukam Buka Latihan Bersama 18 Negara" [online]. dalam https://tniad.mil.id/2014/o3/ menkopolhukam-buka-latihan-bersama-18-negara/ [diakses 27 Juni 2019]. 
Tribunnews, 2018a. "Pangkalan TNI terpadu Natuna Beroperasi" [online]. dalam http://medan.tribunnews.com/2018/12/ 21/pangkalan-tni-terpadu-natuna-beroperasi-gabungantiga-angkatan-ini-foto-dan-videonya [diakses 16 Mei 2019].

Tribunnews, 2018b. “Tribun News: Penampakan Pangkalan Militer di Natuna, Siap Jaga Wilayah NKRI dari Caplokan Negara Asing" [online]. dalam http://medan.tribunnews. com/2018/12/21/penampakan-pangkalan-militer-dinatuna-siap-jaga-wilayah-nkri-dari-caplokan-negaraasing?page $=4$ [diakses 22 Juni 2019].

United Nations, 2009. "United Nations" [online]. dalam http://www.un.org/depts/los/clcs_new/submissions_ files/vnm37_09/chn_2009re_vnm.pdf [diakses 12 April 2019].

Viva, 2019. "China Latihan Angkatan Laut Gabungan dengan 6 Negara Asia Tenggara" [online]. dalam https://www.viva.co.id/berita/dunia/1143643-chinalatihan-angkatan-laut-gabungan-dengan-6-negara-asiatenggara [diakses 23 Juni 2019]. 
Naval Diplomacy: Upaya Defensif Indonesia

dalam Konflik Laut Tiongkok Selatan di Era Joko Widodo 